\title{
Effect of feeding Leucaena pallida with concentrate and antihelmentic treatment on growth performance and nematode parasite infestation of Horro ewe lambs in Ethiopia
}

\author{
Chala Merera $^{1 \star}$, Temesgen Ayana ${ }^{1}$ and Tegegn Gudeta ${ }^{2}$ \\ ${ }^{1}$ Ambo University, P. O. Box 19, Ethiopia. \\ ${ }^{2}$ Bako Agricultural Research Center, P. O. Box 03, Ethiopia.
}

Accepted 22 November, 2013

\begin{abstract}
The study was conducted to investigate the effect of supplementing Leucaena pallida in reducing gastrointestinal parasite load and to evaluate growth response of Horro ewe lambs to supplementation and antihelmentic treatment. A total of $\mathbf{3 2}$ Horro ewe lambs were randomly assigned to four treatments: Grazing, grazing + antihelmintics only, grazing + $500 \mathrm{~g}$ dried Leucaena pallida leaves + $200 \mathrm{~g}$ ground maize grain per head/day, and grazing $+200 \mathrm{~g}$ noug cake $+200 \mathrm{~g}$ ground maize grain per head/day with eight replicates. Feeding $L$. pallida leaves increased $(P<0.05)$ growth rates and reduced $(P<0.05)$ nematode parasite egg counts (Eggs per gram of faeces (EPG)) compared with un-supplemented Horro ewe lambs. Packed cell volume $(P C V)$ was significantly increased $(P<0.05)$ in Horro ewe lambs supplemented with $L$. pallida and concentrate and treated with antihelmentic compared to the animals assigned to grazing alone. The results revealed that supplementation of $L$. pallida with concentrate have beneficial anti-parasitic properties and improved the growth performance of Horro ewe lambs.
\end{abstract}

Key words: Eggs per gram of faeces (EPG), packed cell volume (PCV), nematode, Leucaena pallida, Horro ewe lambs.

\section{INTRODUCTION}

Productivity of small ruminants in many tropical areas is often low and has been related to limitations caused by parasites, inadequate nutrition, unimproved genotypes and poor management (Devendra and Burns, 1983). About $80 \%$ of the national sheep population is reported to harbor varying degrees of infection with different species of nematode parasites. Parasitic infection has a significant effect in reducing productivity of sheep. Reduction in productivity can be expressed in terms of slow growth rate and mortality. Studies show that parasitism is one of the causes of mortality in sheep. For instance, out of the deaths in Horro sheep, $8.7 \%$ attributed to endo-parasitism (Markos et al., 2004a) and control of endo-parasites is among contributing factors in increasing sheep productivity. The interaction between the level of nutrition and the ability of animals to cope with internal parasites has long been recognized. Protein supplementation has shown to improve the resistance of lambs to endoparasites (Aynalem et al., 2002; Mukasa et al., 1991).

Parasitic nematodes of the digestive tract remain one of the main constraints to small ruminant production in tropical countries (Hoste et al., 2005). The usual mode of control of these gastrointestinal nematodes based on 
repeated use of antihelmintics is now strongly questioned because of the increasing development of resistance to chemical medicines (Waller and Chandrawathani 2005). The manipulation of host nutrition in order to improve the host resistance and/or resilience to parasite infections seems to represent one of the most promising options (Hoste et al., 2005). Small ruminants which are well nourished grow and reproduce faster and are better able to withstand the effects of worm infection than those given a low plane of nutrition (Peacock, 1996).

Drug resistance has become an important issue in small ruminant husbandry when antihelmintics are applied at high levels and at increasing frequency and with inappropriate doses (Pandey et al., 2001; Chartier et al., 1998). The use of natural substances is becoming preferable and may offer better control than using chemical compounds to treat parasitised animals (Chandrawathani et al., 2003).

Nowadays the impact of parasitism is becoming a serious problem in sheep production activity and as well contributing to sheep mortality. Thus, controlling gastrointestinal parasites is of a great importance in increasing sheep productivity. Control measures against internal parasites known to-date include the use of chemotherapy (antihelmentic), and/or controlled grazing, exploiting genetic variation in host resistance and improved nutrition to aid the development of immunity (Aynalem et al., 2002).

A chemical control program is the most widely used method for internal parasite control throughout the world (Jones and Bray, 1983). Many different commercial products are available to remove internal parasites from small ruminants in which the drugs are available and produced in several different physical forms and sold under various brand names. It is increasingly evident that gastrointestinal parasite (GIP) control programs based on de-wormers are failing because of increased de-wormer resistance; thus, alternative GIP control strategies are necessary. Recent studies have reported that antiparasite agents extracted from plant materials for the control of parasites were successful (Nguyen et al., 2003). The research on effect of Cassava and Jack fruit leaves in diet on infection rates of intestinal nematodes and live weight gain of goats has been done. The results of counted strongyle eggs and coccidian oocyts were much lower with the goat fed foliage of Jackfruit and Cassava (Nguyen et al., 2003).

Previous studies showed that feeding cassava foliage hay to goats resulted in improved growth performance (Ngo et al., 2005; Phengvichith and Ledin, 2006). Apart from the nutritional benefit that has been obtained in ruminants fed on cassava foliages containing a moderate concentration of tannins, a reduction in the number of parasite eggs in the faeces has been also observed (Netpana et al., 2001; Seng and Preston, 2003; Ngo et al., 2005; Nguyen et al., 2005).

The effect of using cassava leaves to control nematode parasite infestation in dairy cattle and buffaloes showed that the lowest level of eggs per gram of faeces (EPG) of nematode and the highest growth rate in animals fed with the plant (Netpana et al., 2001; Seng and Rodriguez, 2001). Sheep and goat grazing condensed tannincontaining legumes were shown to better tolerate internal parasite infections than those grazing non condensed tannin containing forages (Nguyen et al., 2003). Thus, the objectives of this study were to investigate the effect of supplementing L. Pallida in reducing gastrointestinal parasite load of Horro ewe lambs and to evaluate differential response of Horro ewe lambs to supplementation and antihelmentic treatment.

\section{MATERIALS AND METHODS}

\section{Location and climate of experiment site}

The experiment was conducted at Bako Agricultural Research Center which is located $250 \mathrm{Km}$ west of Addis Ababa at an altitude of $1650 \mathrm{~m}$ above sea level. The center received mean annual rainfall of $1200 \mathrm{~mm}$ in a bimodal distribution, $80 \%$ of which falls from May to September. The area had a mean relative humidity of $59 \%$ and mean minimum and maximum temperatures of 13.5 and $27^{\circ} \mathrm{C}$, respectively. The experiment was carried out for 90 days from the beginning up to the end of the wet season (June 20 to September 20, 2010).

\section{Animal management and treatment}

A total of 32 Horro ewe lambs were purchased from local Hareto market located at Jimma-Rare district, Horro Gudur zone. They were approximately one year old by looking teeth of ewe lambs (Vatta et al., 2006) and weighed $14.0 \pm 0.5 \mathrm{~kg}$. The animals were kept on grazing pasture only (without any supplement) for quarantine period of two weeks and housed during the night in sheltered pens. All animals were drenched against nematodes with Fenbendazole (Panacur® Hoechst Ltd, UK) and against trematodes with Tricalbendazole (Fasinex ®CIBA-GEIGY, Switzerland) two weeks prior to the commencing of the actual experiment. They were vaccinated against ovine pasteurollosis and sheep pox. Individual animals were treated against any other infectious disease than for gastrointestinal parasites.

The animals were assigned in a completely randomized block design to four treatments with eight animals per treatment. The treatments were:

1. $G=$ Grazing only,

2. $\mathrm{GAH}=$ Grazing + Antihelmintics treatment only,

3. GLCS $=$ Grazing $+500 \mathrm{~g}$ dried Leucaena leaves $+200 \mathrm{~g}$ ground maize per head/day,

4. $\mathrm{GCS}=$ Grazing $+200 \mathrm{~g}$ noug cake $+200 \mathrm{~g}$ ground maize grain per head/day.

Horro ewe lambs assigned to antihelmentic treatment group were drenched against nematodes with Fenbendazole at a doze rate of 5 $\mathrm{mg} / \mathrm{kg}$ live body weight (Tembely et al., 1996). The animals were managed in flock and grazed on natural pasture from 9:00 to 15:00 to give enough exposure time to natural infection. For the sun dried Leucaena pallida, the foliage was harvested and dried for about two days under shade and the sun-dried foliage stored in bags until needed. The feeds were offered two times per day in the morning at 
Table 1. Mean values of change in live weight of Horro ewe lambs fed different supplements with $L$. pallida, concentrate and treated with antihelmentic.

\begin{tabular}{lcccc}
\hline \multirow{2}{*}{ Group } & \multicolumn{4}{c}{ Change in live body weight } \\
\cline { 2 - 5 } & Initial weight $\mathbf{( k g})$ & Final weight $\mathbf{( k g})$ & Total weight gain $\mathbf{( k g )}$ & ADG (g) \\
\hline G & 20.29 & $22.35^{\mathrm{b}}$ & $2.36^{\mathrm{b}}$ & $26.22^{\mathrm{b}}$ \\
GAH & 22.15 & $25.25^{\mathrm{b}}$ & $3.10^{\mathrm{b}}$ & $34.44^{\mathrm{b}}$ \\
GLCS & 19.32 & $26.20^{\mathrm{a}}$ & $6.88^{\mathrm{a}}$ & $76.44^{\mathrm{a}}$ \\
GCS & 22.13 & $30.07^{\mathrm{a}}$ & $7.88^{\mathrm{a}}$ & $87.56^{\mathrm{a}}$ \\
SE & \pm 1.19 & \pm 1.93 & \pm 0.87 & \pm 0.01 \\
\hline
\end{tabular}

G: grazing only; GAH: grazing + antihelmintics only; GLCS: grazing + $500 \mathrm{~g}$ dried Leucaena leaves+ $200 \mathrm{~g}$ ground maize per head/day; GCS: grazing $+200 \mathrm{~g}$ noug cake $+200 \mathrm{~g}$ ground maize grain per head/day. ${ }^{\text {abc }}$ Means within rows without common superscript differ significantly at $P<0.05$.

8:00 am and in the afternoon at 4:00 pm. Water was provided ad libitum. The animals were allowed for one week adaptation period before starting the experiment to accustom the ewe lambs to the housing and the feeding systems.

\section{Measurements/sample collection}

The amounts of feed offered and refused were measured and recorded daily; separately for the basal diet and the supplements. Live weight was recorded at the beginning, fortnightly and at the end of the experiment before the animals released for grazing.

Blood samples for haematocrit values (PCV) were collected fortnightly from ear vein punctures in to heparinized capillary tubes. Fecal samples for parasite egg counts were collected fortnightly from the rectum of the experimental animals and counts were made using the modified McMaster method and expressed as egg per gram of faeces (EPG). The samples were analyzed following Schalm et al. (1975). To determine EPG, about $4 \mathrm{~g}$ of faecal samples were grinded and mixed with $56 \mathrm{ml}$ of flotation fluid (a saturated sugar solution in water). After filtering through a "tea strainer", a sub-sample was transferred to both compartments of a McMaster counting chamber and allowed to stand for $5 \mathrm{~min}$. All parasite eggs were counted under a microscope at $10 \times 10$ magnifications and multiplied by 50 to yield the EPG of faeces (Hansen and Perry, 1994). At the end of the trial, necropsy was done on some randomly selected animals from each treatment group for worm counts. Two ewe lambs from each treatment were slaughtered to determine the total worm burden in the intestinal gut. The eggs in the faeces were cultured to identify the species of the infective larva using the faecal sample from the slaughtered animals.

\section{Statistical analysis}

Data were analyzed using the General linear model of Statistical Analysis System (SAS, 2003). During analysis, treatment was considered as independent variables whereas average daily weight gain, PCV and EPG considered as dependent variables.

\section{RESULTS AND DISCUSSION}

\section{Feed intake and live weight gain of Horro ewe lambs}

Almost all concentrate and L. pallida supplements were consumed by treatment animals so that the feed refusals of the supplements were nil in this experiment. Average daily live weight gain (ADG) was higher $(P<0.05)$ for Horro ewe lambs supplemented with $L$. pallida and concentrate compared with the un-supplemented control and antihelmentic treatments (Table 1). The faster growth rates in supplement treatments probably relate to the growth potential of Horro sheep breed and the higher protein content of the supplements. These results are in agreement with Solomon et al. (1996) who reported Horro lambs given no supplementary feed and grazed on natural pasture in the dry season lost weight while the supplemented lambs gained weight. Galal (1983) made a similar observation for the same sheep breed kept on cultivated pasture in the dry season when the stocking rate was high. There was no significant difference in growth rate between control and drenched Horro ewe lambs treatments due to the fact that drenching with antihelmentic did not result in better growth if the nutritional level was not improved. Similar results were reported by Pralomkarn et al. (2001).

\section{Parasite infestation}

Eggs per gram of faeces (EPG) were significant reduced $(P<0.05)$ in Horro ewe lambs supplemented with $L$. pallida and treated with antihelmentic treatment compared to the grazing alone (Tables 2 and 3). EPG was also lower $(P<0.05)$ for Horro ewe lambs drenched with antihelmentic compared to supplementation with $L$. pallida and concentrate. A reduction in nematode infestation in ewe lambs supplemented with L. pallida leaves, compared with ewe lambs graze alone, as evidenced by lower EPG values in faeces, was reported by Seng and Rodriguez (2001); Seng and Preston (2003). In more detailed studies (Seng et al., 2009) it was shown that goats fed both cassava foliage had reduced worm fecundity (reduced EPG) beneficial effects of the improved protein status on the health of the goats fed cassava foliage could also be expected as it has been shown that protein supplementation of infected sheep or goats helped them to mount an effective immunological 
Table 2. Mean values for EPG (eggs per gram of faeces) of the Horro ewe lambs supplemented with L. pallida concentrate and treated with antihelmentic.

\begin{tabular}{|c|c|c|c|c|c|}
\hline \multirow{2}{*}{ Group } & \multirow{2}{*}{$\begin{array}{l}\text { Overall EPG for the } \\
\text { group }\end{array}$} & \multicolumn{4}{|c|}{ Eggs per gram of faeces (EPG) } \\
\hline & & June & July & August & September \\
\hline $\mathrm{G}$ & $2715.32^{c}$ & $2531.25^{c}$ & $3382.5^{c}$ & $2635^{c}$ & $2312.5^{\mathrm{c}}$ \\
\hline GLCS & $1165.63^{b}$ & $918.75^{b}$ & $981.25^{\mathrm{b}}$ & $1325^{\mathrm{b}}$ & $1437.5^{b}$ \\
\hline GCS & $1150^{b}$ & $862.5^{\mathrm{b}}$ & $1131.3^{b}$ & $1337.5^{\mathrm{b}}$ & $1268.75^{\mathrm{b}}$ \\
\hline Overall & 1369.61 & $1102.19^{b}$ & $1484.69^{b}$ & $1525.94^{b}$ & $1365.63^{b}$ \\
\hline
\end{tabular}

G: grazing only; GAH: grazing + antihelmintics only; GLCS: grazing + $500 \mathrm{~g}$ dried Leucaena leaves+ $200 \mathrm{~g}$ ground maize per head/day; GCS:

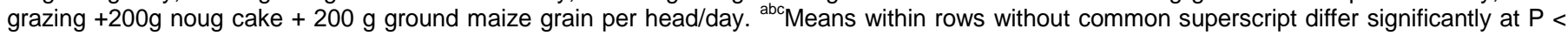
0.05 .

Table 3. Mean values for EPG parasite (Fasciola, Paramphistomum, Haemonchus, Coccidia, Trichuris and Nematodes) of Horro ewe lambs supplemented with L. pallida and treated with antihelmentic.

\begin{tabular}{lcccccc}
\hline \multirow{2}{*}{ Group } & \multicolumn{7}{c}{ EPG parasite } \\
\cline { 2 - 7 } & Fasciola & Paramphistomum & Haemonchus & Coccidia & Trichuris & Nematodes \\
\hline G & $1410.72^{\mathrm{c}}$ & $330^{\mathrm{c}}$ & $905.58^{\mathrm{b}}$ & $207.14^{\mathrm{c}}$ & $315.95^{\mathrm{b}}$ & $533^{\mathrm{a}}$ \\
GAH & $235.63^{\mathrm{a}}$ & $75^{\mathrm{a}}$ & $268.01^{\mathrm{a}}$ & $50^{\mathrm{a}}$ & $127^{\mathrm{a}}$ & \\
GLCS & $382.15^{\mathrm{b}}$ & $115^{\mathrm{b}}$ & $421.21^{\mathrm{a}}$ & $133.33^{\mathrm{a}}$ & $135.42^{\mathrm{a}}$ & -- \\
GCS & $423.36^{\mathrm{b}}$ & $230^{\mathrm{b}}$ & $455.58^{\mathrm{a}}$ & $50^{\mathrm{a}}$ & $174.82^{\mathrm{a}}$ & $250^{\mathrm{b}}$ \\
SE & \pm 113.07 & \pm 102.58 & \pm 77.85 & \pm 73.23 & \pm 50.36 & \pm 47.14 \\
\hline
\end{tabular}

${ }^{\mathrm{abc}}$ Means within rows without common superscript differ significantly at $P<0.05$.

response to the infection (Hoste et al., 2005). The data for worm egg counts support the earlier findings of Seng and Rodríguez (2001), with much lower EPG on the cassava supplement in experiment. The difference was that the degree of infestation was much less in this experiment than in the study of Seng and Rodríguez (2001), who reported that the EPG counts were high on the grazing alone treatment and showed a steady decline during the experiment from about 4000 to 5000 in the first 30 days to about 1500 after 70 days.

There were no significant differences in EPG between the months (Table 2). On the unsupplemented control treatment, the parasite infection increased almost inconsistely for 90 days close to three thousand EPG. On the $L$. pallida treatment, the EPG counts increased inconsistely over time but to a much lesser extent than on the control or grazing treatment. From this result, it would appear that $L$. pallida foliage contains compounds (presumably the condensed mimosine) that have an antihelmentic effect against nematode parasites in ewe lambs. In this respect, there are many reports in the literature that describe such an action to the presence of condensed tannins and mimosine (Granum et al., 2003; Butter et al., 2000; Kabasa et al., 2000; Molan et al., 2002; Kahn and Diaz., 2001).

Other indirect effects of $L$. pallida foliage could be the higher level of protein as compared to grass and the expectation that the mimosine and tannins present in Leucaena and cassava foliage will enhance the supply of essential amino acids to the small intestine (Wanapat, 2003). The importance of the protein nutrition of the host animal as a factor enabling it to overcome parasitism has been emphasized by many authors (Coop and Kyriazakis, 2001; Aynalem et al., 2002; Nolan, 1999). A high level of protein nutrition is also important in developing natural immunity against nematode parasites (Nolan, 1999).

Examination of the larvae cultured from the eggs in the faeces samples showed that the parasite or worms were almost entirely of the Haemonchus contortus and Strongylus species (Table 3). Sokerya et al. (2007) also reported that $H$. contortus was the most abundant species, accounting for more than $50 \%$ of the worm burdens in tropics.

Packed cell volume (PCV) was significantly increased $(P<0.05)$ in Horro ewe lambs supplemented with $L$. pallida and concentrate and treated with antihelmentic compared to the animals assigned to grazing alone (Table 4). This might be related to the fact that the burdens of parasites were significantly reduced with $L$. pallida and antihelmentic treatments so that worms suckling the blood of animals and share the nutrients might be reduced. However, there was no significant $(P$ $>0.05$ ) difference in PCV between ewe lambs treated with 
Table 4. PCV (least square means \pm SE) from Horro ewe lambs supplemented with $L$. pallida, concentrate and treated with antihelmentic during different months.

\begin{tabular}{lccccc}
\hline \multirow{2}{*}{ Group } & $\begin{array}{c}\text { Overall PCV for } \\
\text { the group }\end{array}$ & June & July & Pugust & September \\
\cline { 3 - 6 } & $20.05^{\mathrm{b}}$ & $20.94^{\mathrm{b}}$ & $21.63^{\mathrm{b}}$ & $19.69^{\mathrm{b}}$ & $17.94^{\mathrm{b}}$ \\
$\mathrm{G}$ & $25.21^{\mathrm{a}}$ & $24.3^{\mathrm{a}}$ & $25.31^{\mathrm{a}}$ & $25.32^{\mathrm{a}}$ & $25.89^{\mathrm{a}}$ \\
GAH & $26.08^{\mathrm{a}}$ & $25.63^{\mathrm{a}}$ & $24.82^{\mathrm{a}}$ & $26.19^{\mathrm{a}}$ & $27.69^{\mathrm{a}}$ \\
GLCS & $26.97^{\mathrm{a}}$ & $27.13^{\mathrm{a}}$ & $26.75^{\mathrm{a}}$ & $27.00^{\mathrm{a}}$ & $27.0^{\mathrm{a}}$ \\
GCS & \pm 2.07 & \pm 1.99 & \pm 1.98 & \pm 1.95 & \pm 2.36 \\
SE & & &
\end{tabular}

G: grazing only; GAH: grazing + antihelmintics only; GLCS: grazing + $500 \mathrm{~g}$ dried Leucaena leaves + $200 \mathrm{~g}$ ground maize per head/day; GCS: grazing $+200 \mathrm{~g}$ noug cake $+200 \mathrm{~g}$ ground maize grain per head/day. ${ }^{\text {ab }}$ Means within rows without common superscript differ significantly at $\mathrm{P}<0.05$.

antihelmentic and supplemented with concentrate containing L. pallida. PCV was not significantly different over the period of months. These results are similar to the result from the study by Nguyen et al. (2003). Sokerya et al. (2007) also reported that during the time that egg counts were rapidly increasing, there were correspondingly decreasing trajectories of PCV in all groups.

\section{CONCLUSIONS AND RECOMMENDATION}

The objectives of this study were to investigate the effect of supplementing L. pallida in reducing gastrointestinal parasite load and to evaluate differential response of Horro ewe lambs to supplementation and antihelmentic treatment. Average daily live weight gain was higher $(P<$ $0.05)$ for Horro ewe lambs supplemented with $L$. pallida and concentrate compared with the un-supplemented control and antihelmentic treatment. EPG counts (eggs per gram of faces) were significantly reduced $(P<0.05)$ in Horro ewe lambs supplemented with L. pallida and treated with antihelmentic treatment compared to the grazing alone. EPG was also lower $(P<0.05)$ for Horro ewe lambs drenched with antihelmentic compared to supplementation with $L$. pallida and concentrate treatments. Packed cell volume (PCV) was significantly increased $(P<0.05)$ in Horro ewe lambs supplemented with L. pallida and concentrate and treated with antihelmentic compared to the animals assigned to grazing alone. Supplementation of $L$. pallida had improved growth rate, reduced level of EPG of nematode in controlling parasite infestation and increased the level of PCV in Horro ewe lambs. Therefore, it can be suggested that $L$. pallida supplementation could be used as control method for internal parasite in addition to providing higher protein content for Horro ewe lambs.

\section{ACKNOWLEDGEMENT}

The authors would like to thank Oromia Agricultural
Research Institute for financial support. They also wish to thank and appreciate Mr. Yosef Kiros and Tesfaye Tadesse for their cooperation during data collection.

\section{REFERENCES}

Aynalem H, Tembely S, Anindo DO, Mukasa E, Rege JE, Alemu Y, Baker RL (2002). Effects of breed and dietary protein supplementation on the responses to gastrointestinal nematode infections in Ethiopian sheep. Small Rum. Res. 44(3):247-261.

Butter NL, Dawson JM, Wakelin D, Buttery J (2000). Effect of dietary tannin and protein concentration on nematode infection (Trichostrongylus colubriformis) in lambs. J. Agric. Sci. 134:89-99.

Chandrawathani P, Waller PJ, Adnan M, Höglund J (2003). Evolution of high level, multiple anthelmintic resistances on a sheep farm in Malaysia. Trop. Anim. Health. Prod. 35:17-25.

Chartier C, Pors I, Hubert J, Rocheteau D, Benoit C, Bernard N (1998). Prevalence of anthelmintic resistant nematodes in sheep and goats in western France. Small Rumin. Res. 29:33-41.

Coop RL, llias K (2001). Influence of host nutrition on the development and consequences of nematode parasitism in ruminants. Trends Parasitol. 17(7):325-330.

Devendra C, Burns M (1983). Goat Production in the Tropics, 2nd edition. Commonwealth Agriculture Bureau, Slough, UK. P. 183.

Galal ES (1983). Sheep Germplasm in Ethiopia. Animal Genetic Information. FAO (Food and Agriculture Organization of the United Nations), Rome. Italy, pp. 4-12.

Granum G, Wanapat M, Wachirapakorn C, Pakdee P (2003). A comparative study on the effect of cassava hay in swamp buffaloes (Bubalus bubalis) and cattle (Bos indicus). MSc thesis, Dept. Animal Science, Khon Kaen University, Khon Kaen, Thailand.

Hansen J, Perry B (1994). The epidemiology, diagnosis and control of helminth parasites of ruminants: A handbook. ILRAD (International Livestock Research for Animal Disease), Nairobi, Kenya. P. 79.

Hoste H, Torres JF, Paolini V, Aguilar CA, Etter E, Lefrileux Y, Chartier C, Broqua C (2005). Interactions between nutrition and gastrointestinal infections with parasitic nematodes in goats. Small Rumin. Res. 60:141-151.

Jones RJ, Bray RA (1983). Agronomic research in the development of leucaena as a pasture legume in Australia. In: Leucaena Research in the Asian-pacific Region. Workshop Proceeding in Singapore, pp. 4148.

Kabasa JD, Opuda AJ, Meulen U (2000). The effect of oral administration of polyethylene glycol on faecal helminth egg counts in pregnant goats grazed on browse containing condensed tannins. Trop. Anim. Health. Prod. 32:73-86.

Kahn LP, Diaz HA (2001). Tannins with anthelmintic properties. In Brooker J.D. (ed) Tannins in Livestock and Human Nutrition. ACIAR Proc. 92:130-140.

Molan AL, Waghorn GC, McNabb WC (2002). Effect of condensed 
tannins on egg hatching and larval development of Trichostrongylus colubriformis in vitro. Veterinary Record. 150:65-69.

Mukasa ME, Kasali OB, Said AN (1991). Effect of nutrition and endoparasite treatment on growth. Theriogenology 36:319-328

Netpana N, Wanapat M, Poungchompu O, Toburan W (2001) Effect of condensed tannins in cassava hay on fecal parasitic egg counts in swamp buffaloes and cattle. In: Proceedings International Workshop on Current Research and Development on Use of Cassava as Animal Feed (Eds. Preston TR, Ogle B, Wanapat M), Khon Kaen, Thailand.

Ngo TD, Nugyen TM, Ledin I (2005). Effect of replacing a commercial concentrate with cassava hay (Manihot esculenta Crantz) on the performance of growing goats. Anim. Feed Sci. Technol. 119:271281.

Nguyen KL, Preston TR, Dinh VB, Nguyen DL (2003). Effects of tree foliages compared with grasses on growth and intestinal nematode infestation in confined goats. Livestock Res. Rural Develop. 15:6.

Nguyen TM, Dinh VB, Ørskov ER (2005). Effect of foliages containing condensed tannins and on gastrointestinal parasites. Anim. Feed Sci. Technol. 121:77-87.

Nolan JV (1999). Management of parasitic disease in livestock- can resistance be programmed by dietary manipulation? Recent Adv. Anim. Nutr. Australia 12:7-14.

Pandey VS, Pralomkrarn W, Kochapakdee S, Saithanoo S (2001). Benzimidazol resistance in Haemnchus Contortus from goat in Thailand. PSU goat research publication. P. 337.

Peacock C (1996). Improving Goat Production in the Tropics. Manual for Development workers. Oxfam/Farm Africa Publishing, Oxford, UK and Ireland.

Phengvichith V, Ledin I (2006). Effects of supplementing Gamba grass (Andropogon gayanus) with cassava (Manihot esculenta, Crantz) hay and cassava root chips on feed intake, digestibility and growth in goats. Asian-Austr. J. Anim. Sci. 20(5):725-732.

Pralomkarn W, Kochapakdee S, Choldumrongkul S, Saithanoo S (2001). Effect of supplementation and parasitic infection on productivity of Thai native and cross-bred. 1. Growth, Parasite infestation and blood constituents, PSU goat research publication. pp 291-302.

SAS (2003). Statistical Analysis System. SAS for Windows, Release 9.1 (2002-2003). SAS Institute Inc., Cary, NC, USA.

Schalm OW, Jain NC, Carrol E (1975). Veterinary hematology $3^{\text {rd }}$ Edition Lea and Febiger, Philadelphia USA, pp. 160-210.

Seng S, Try P, Waller PJ, Höglund J (2009). The effect of long-term feeding of fresh and ensiled cassava (Manihot esculenta) foliage on gastrointestinal nematode infections in goats. Trop. Anim. Health Prod. 41: 251-258.
Seng S, Preston TR (2003). Effect of grass or cassava foliage on growth and nematode parasite infestation in goats fed low or high protein diets in confinement. Livestock Res. Rural Develop 15:8.

Seng S, Rodríguez L (2001) Foliage from cassava, Flemingia macrophylla and bananas compared with grasses as forage sources for goats: effects on growth rate and intestinal nematodes. Livestock Res. for Rural Develop. 13:2.

Sokerya S, Peter JW, Inger L, Johan H (2007) The effects of short-term feeding of fresh cassava (Manihot esculenta) foliage on gastrointestinal nematode parasite infections in goats in Cambodia. Trop. Biomed. 24(1):47-54.

Solomon A, Demmissie T, Lemma G (1996) Compensatory growth in Horro lambs of Ethiopia. http://www.fao.org/wairdocs/ilri/x5473b/x5473b1p.htm.

Tembely S, Lahlou KA, Sovani S, Rege JE, Baker RL, Anindo D, Mukasa ME (1996). Small ruminant management practices and control of helimenthosis under traditional production systems in the cool Ethiopian highlands. In: Small Ruminant Research and Development in Africa. Proceedings of the third Biennial conference of the African SRNET, UICC, Kampala, Uganda. pp. 149-158.

Markos T, Aragaw K, Deresa A (2004a) Effects of anthelmintics and supplementation on productivity of Menz and Menz-Awassi crossbred sheep with sub-clinical helimenthosis. Ethiopian Vet. J. 8(2):1-22.

Waller PJ, Chandrawathani P (2005) Haemonchus contortus: Parasite problem No. 1 from Tropics - Polar Circle. Problems and prospects for control based on epidemiology. Trop. Biomed. 22:131-137.

Wanapat M (2003). Manipulation of cassava cultivation and utilization to improve protein to energy biomass for livestock feeding in the tropics. Asian-Austr. J. Anim. Sci. 16:463-472.

Vatta AF, Abbot MA, Villiers JF, Gumede SA, Harrison LJS, Krecek R, Letty BA, Mapeyi N, Pearson RA (2006). Goat Keepers' Animal Health Care Manual. Agricultural Research Council. Onderstepoort Veterinary Institute with KwaZulu-Natal Department of Agriculture and Environment, South Africa. P. 60. 